TAPROBANICA, ISSN 1800-427X. April, 2013. Vol. 05, No. 01: pp. 50-59.

(C) Taprobanica Private Limited, 146, Kendalanda, Homagama, Sri Lanka.

www.taprobanica.org

\title{
BAT FAUNA OF THE WESTERN HIMALAYA OF INDIA: A ZOOGEOGRAPHIC PERSPECTIVE
}

\author{
Uttam Saikia $^{1}$ and Ananda Ram Boro ${ }^{2}$
}

\footnotetext{
${ }^{1}$ North Eastern Regional Centre, Zoological Survey of India, Fruit Garden, Risa Colony, Shillong 793003, India E-mail: uttamzsi@gmail.com

${ }^{2}$ Department of Zoology, Pandu College, Guwahati, India
}

\begin{abstract}
A zoogeographic analysis of the chiropteran fauna of western Himalayan states of Himachal Pradesh (HP) and Jammu \& Kashmir (J\&K) is presented. Based on field surveys, study of museum specimens and published literature, 44 species of bats in 20 genera have been reported from the study area. By virtue of its transitional position between the Oriental and Palearctic biogeographic realms, the chiropteran fauna of western Himalaya exhibit an intermixing of elements from both the realms. At the species level, Oriental elements (25 species) dominate Palearctic (17 species) and Ethiopian (1 species) components, while the zoogeographic affinity of one species, Miniopterus schreibersii, is indeterminate. Some zoogeographic aspects influencing the present faunal composition of the region are also discussed. Considering the lack of studies on bat fauna in this part of the Himalaya, it is expected that intensive studies will shed new light into the zoogeography of these lesser known mammals.
\end{abstract}

Key words: Chiroptera, species diversity, zoogeographic affinity, disjunctive distribution

\section{Introduction}

The Himalaya extends over a distance of about $2500 \mathrm{~km}$ between $26^{\circ} 20^{\prime}-35^{\circ} 40^{\prime} \mathrm{N}$ and $74^{\circ}$ 50' - 95 40' E (Ives \& Messeril, 1989). The range is geographically partitioned into Eastern Himalaya, Central Himalaya, Western Himalaya and Northwest Himalaya (Mani, 1974a). Within Indian limits, Himalaya occupies an area of $531,250 \mathrm{~km}^{2}$ comprising $16.6 \%$ of the total geographical area of the country (Nandi et al., 2000) and it is further divided into Northeastern Himalaya comprising the states of Northeastern India, Central Himalaya including Uttarakhand State and Western Himalaya consisting of the states of Himachal Pradesh (HP) and Jammu \& Kashmir (J\&K) (Ahmed et al., 1990). By virtue of exceptional diversity and endemicity of life forms, Himalaya is recognized as one of the 34 
biodiversity hotspots of the world (Mittermier et al., 2004). Biogeographically, the Himalaya constitutes a transition zone between the Palearctic and the Indo-Malayan realms and an intermixing of species from both realms is evident in its faunal composition (Corbett \& Hill, 1992). Tremendous altitudinal gradient of the mountain range results in topographic variations and consequent multiplicity of ecosystems harbouring different ecological communities. Thus, the mesmerizing biodiversity of the region is the consequence of complex interplay between biogeographic, altitudinal and topographic factors.

Bats (order Chiroptera) constitute one of the most species-rich and ubiquitous mammalian orders, comprising over 1100 species (Simmons, 2005). The order consists of two suborders: Yinpterochiroptera comprising the families Pteropodidae, Rhinolophidae, Megadermatidae, Craseonycteridae and Rhinopomatidae; and Yangochiroptera encompassing the families Emballonuridae, Nycteridae, Phyllostomidae, Mormoopidae, Noctilionidae, Furipteridae, Thyropteridae, Mystacinidae, Myzopodidae, Vespertilionidae, Molossidae and Natalidae (Teeling et al., 2005). In the Indian subcontinent, the order is represented by 121 species belonging to 37 genera and eight families, of which 112 species in 33 genera and eight families occur within India (Srinivasalu \& Srinivasalu, 2001).

The first report on the bat fauna of western Himalaya was that of Dobson (1872), who described Vespertilio macropus (=Myotis longipes) from the Bhima Devi area of Kashmir valley. Subsequently, he described Vespertilio murinoides (=Myotis blythii) from the Chamba area of HP (erstwhile Punjab) (Dobson, 1873). Blanford, (1888-1891) in his "Fauna of British India" book, also listed a few bat species from this region like Myotis muricola from Dalhousie and Shimla and Barbastella leucomelas from Shimla. Subsequently, Allen (1908) reported Rhinolophus ferrumequinum, Scotophilus kuhlii and Scotoecus pallidus from Kullu valley of HP. Dodsworth (1913) recorded seven species of bats, namely Pteropus giganteus, Rhinolophus ferrumequinum tragatus, Nyctalus montanus, $N$. labiatus, Myotis muricola, M. blythii and Pipistrellus coromandra from Shimla and the adjoining hill region. Thomas (1911, 1926) described
Plecotus wardi (earlier treated under $P$. austriacus, this taxon is presently considered distinct - Spitzenberger et al., 2006) and Myotis meinertzhageni $(=M$. nipalensis $)$ (Simons, 2005) from the Ladakh area. The mammal survey organized by the Bombay Natural History Society during 1912-1920 generated momentum for mammalian studies in the Indian subcontinent and as a part of that the western Himalayan region was also surveyed by workers like Major Stockley and H. W. Wells. The report on the Chamba and Kangra areas of HP was published by Lindsay (1927) and that of Kashmir (covering the Islamabad District of Pakistan-occupied Kashmir) and Punjab by Hinton and Thomas (1926). The reports included a number of species from western Himalaya, namely Pteropus giganteus, Rhinolophus ferrumequinum tragatus, Pipistrellus javanicus (as P. babu in Lindsay, 1927), Nyctalus noctula (as N. labiatus in Lindsay, 1927), Nyctalus leisleri, Myotis nipalensis (as M. muricola in Lindsay, 1927), Myotis muricola and Plecotus wardi. During 1966-1970, H. R. Bhat and his associates of the National Institute of Virology in Pune surveyed various parts of Western Himalaya for a study on vertebrate ectoparasites. They collected and documented several bat species from Himachal Pradesh including Plecotus homochrous (as P. auritus) from Ratandi, Shimla district, which was the first report of this species from the state (Bhat et al., 1983). Sharma \& Sharma (1976) reported some mammal species from Jammu valley including Pipistrellus mimus (=P. tenuis). Nath $(1979,1985,1987)$ also reported a number of bat species from Kashmir valley like Pipistrellus pipistrellus, P. coromandra, $P$. paterculus and Otonycteris hemprichi. Chakraborty (1983) provided an account on the mammalian fauna of $J \& K$ including 27 species of bats from the state. The comprehensive work of Bates and Harrison (1997) enumerated a total of 33 species of bats in J\&K and HP. Of late, a number of species, namely Rhinolophus luctus, $R$. affinis, Hipposideros armiger, Hipposideros fulvus, Miniopterus schreibersii and Myotis siligorensis, are added to the chiropteran inventory of the region including range extensions of a few (Saikia et al., 2004, 2006). Recently, Saikia et al. (2011) gave a detailed account on the Chiroptera of HP, however, such consolidated information is lacking for $\mathrm{J} \& \mathrm{~K}$. This article tries to collate 
together the available information on the same and to present it in the light of past zoogeographic history.

\section{Study area}

The western Himalayan states of HP and J\&K cover an area of $278,325 \mathrm{~km}^{2}$ and spread between $30^{\circ} 18^{\prime}-36^{\circ} 58^{\prime} \mathrm{N}$ and $72^{\circ} 30^{\prime}-79^{\circ} 04^{\prime}$ E (Mehta \& Julka, 2002). Biogeographically, the area comes under two biogeographic zones, the Himalaya and the Trans-Himalaya encompassing three biotic provinces (Rodger \& Panwar, 1988). Four parallel physiographic zones in the region are distinguished from south to north, namely, the Shiwalik Himalaya, the Lesser Himalaya, the Great Himalaya and the Trans-Himalaya. The Shiwalik is the outermost foothills zone comprising several highly eroded low ridges and is normally below an elevation of $1500 \mathrm{~m}$. Districts of Sirmour, Solan, Bilaspur, Hamirpur, Una and parts of Chamba and Kangra in HP and the Jammu valley in $\mathrm{J} \& \mathrm{~K}$ are included in this zone. The Lesser Himalaya runs from north of the Shiwalik and parallel to the Great Himalayan range. Pir Panjal and Dhauladhar are the main mountain ranges in this zone. North of the Pir Panjal range lies the Kashmir valley. The Great Himalayan ranges lie towards the north of Kashmir valley, the Chandrabhaga River in Lahaul, and Spiti in HP and comprises great peaks rising up to an elevation of over $6000 \mathrm{~m}$. The Great Himalayan ranges act as a barrier to the southwest monsoon and creates a rain shadow zone north of it, known as TransHimalaya. This region comprises districts of Ladakh and Kargil in J\&K, Lahaul and Spiti valleys and Pooh Tehsil of the District Kinnaur in HP. Average annual rainfall in the area varies from $60 \mathrm{~mm}$ in Trans-Himalayan Ladakh region to about $2500 \mathrm{~mm}$ on the lower slopes of Dhauladhar range in Kangra District of HP. In higher elevations, precipitation occurs mainly in the form of snowfall and areas over $4500 \mathrm{~m}$ remain under snow almost year round. Natural vegetation in western Himalaya can be broadly subdivided in to the following types; (A) Tropical forest: confined to the foothills and consisting of either Acacia and Zizyphus scrub or deciduous Shorea robusta forest, (B) Subtropical forest: develops between 500$1800 \mathrm{~m}$ and comprises species like Terminalia, Albizzia, and Olea (dry evergreen type) or Pinus roxburghii (Chir pine type), (C) Temperate forest: this forest develops between
$1500-3000 \mathrm{~m}$ and features two subtypes, the Himalayan moist temperate subtype which contains Quercus spp., Cedrus deodara, and Pinus wallichiana and the Himalayan dry temperate subtype mainly consisting of Quercus ilex and Pinus gerardiana, (D) Subalpine forest: usually found between 3000$3400 \mathrm{~m}$ and consists of species like Betula utilis, Abies spectabilis and Rhododendron campanulatum, and (E) Dry Alpine scrub: consisting of scrubs of Rhododendron campanulatum or Juniperus communis at altitudes between 3200-3800m (Mehta \& Julka, 2002).

\section{Materials and Methods}

Information on species diversity presented in this account is based on the first author's collections and observations during field surveys in various parts of HP, the chiropteran collection at the High Altitude Regional Centre, the Zoological Survey of India (ZSI) in Solan, and also published literature including museum catalogues. For J\&K State, the data on diversity is almost entirely based on published information except for $H$. fulvus (based on a specimen at ZSI, Solan). For comparison of faunal similarity, the Simpson's coefficient $\left(\mathrm{S}=\mathrm{N}_{\mathrm{C}}(100) / \mathrm{N}_{1}\right.$, where $\mathrm{N}_{\mathrm{C}}=$ number of taxa shared by both regions, $\mathrm{N}_{1}=$ number of taxa in the smaller region) was used (Simpson, 1960). Zoogeographic affinities of the species mentioned are derived from various publications (Chakraborty, 1983; Horáček et al. 2000; Koopman, 1989).

\section{Results and Discussion}

\section{Species diversity and zoogeographic affinity:}

The present account includes 44 species of bats in 6 families and 20 genera known from this part of western Himalaya. This represents an impressive $40 \%$ of the total bat species in India. Vespertilionidae (31 spp) is the largest family followed by Rhinolophidae (6 $\mathrm{spp})$, Pteropodidae (3 spp) and Hipposideridae (2 spp) while families Megadermatidae and Rhinopomatidae are represented by a single species each. Although some of the species are widespread in the region (as evident from multiple recorded localities), a few others like Megaderma lyra, Scotoecus pallidus, Murina tubinaris, Myotis siligorensis, and Pipistrellus paterculus are each known from a single locality record. However, considering the lack of studies on bat fauna of this area, this 
apparent rarity may be an artifact of undersampling rather than rare occurrence. By virtue of its location in the transition zone between the Palearctic and the Oriental realms, the chiropteran fauna of western Himalaya exhibits an admixture of species from both. A single Ethiopian species Rhinopoma hardwickii, which is usually confined to an arid environment, has also been reported from the region. Among the 44 bat species known from this region, 17 are Palearctic, 25 are Oriental, one species has an Ethiopian affinity and another (Miniopterus schreibersii) is of indeterminate origin. The zoogeographic affinities of the bat species are given in Table 1 .

Past faunal inflow: The presence of the Himalaya has been a decisive factor in the distribution of plants and animals in India. While it acted as a barrier for southward and northward movements of Central Asian and Indian species respectively, Himalaya also served as a migration route for flora and fauna and has become the crossroad of different subregions of Palearctic and Oriental realms (Schaller, 1977). The historical influx of fauna from adjacent biogeographic realms to the western Himalaya is evident in the present faunal composition of the area. Nyctalus noctula, Barbastella leucomelas, Plecotus austriacus, Rhinolophus ferrumequinum, Myotis nipalensis, and Pipistrellus pipistrellus are some of the Palearctic representatives of the bat fauna of the region (Corbet \& Hill, 1992; Horáček et al., 2000; Roberts, 1977). These elements might have entered the region either from Iran through Pakistan or down through Himalaya from the Hindukush mountains and Russian Uzbekistan (Roberts, 1977) probably during the ice age (late Tertiary period) (Fig. 2A). A few representatives of the Oriental bat fauna of the region include Pteropus giganteus, Cynopterus sphinx, Megaderma lyra, Hipposideros armiger, Hipposideros fulvus, Rhinolophus affinis, Rhinolophus rouxii, Rhinolophus luctus, and Myotis siligorensis. The possible route of invasion of oriental elements is along the Himalaya through northeastern India (Kurup, 1966, 1974) (Fig. 2B). The lone species with Ethiopian affinity, Rhinopoma hardwickii, may have entered the region from Pakistan through Punjab and Rajasthan (Chakraborty, 1983) (Fig. 2D). However, it would be erroneous to presume that faunal inflow to the region occurred only through the above routes. There may have been several other ways, albeit smaller, through which some mammalian species entered India (Schaller, 1977). For example, Karanth (2003) pointed out that wet zone species from northeast India could have followed multiple corridors during their dispersal to peninsular India through (1) the Vindhya-Satpura range (Fig. 2C), (2) the Eastern Ghats, (3) the Brij area of northern India, and (4) the Aravali range. Although rich in species diversity, the Himalayan region has relatively few endemic bird species (Martens \& Eck, 1995) and the same holds true for mammals. While there is an explanation that species originated in the Himalayas and extended their range postspeciation, the reverse could be true. The Himalayan fauna is predominantly composed of immigrants, from both the Palearctic and Indo-Malayan zoogeographical regions, with very little speciation in situ (Martens \& Eck, 1995) and hence low endemism. Based on recent evidence, the latter hypothesis seems better-grounded (Johansson et al., 2007) and conforms to the faunal dispersal scenario discussed above. With respect to western Himalaya, no endemic species of bats are known.

Faunal similarity, HP vs. J\&K: A variety of factors influence faunal resemblance between different regions e.g. past faunal interchange, similar climatic conditions, indirect spread from a third region and proximity between the regions (Kurup, 1974). A brief comparison of the bat fauna of HP and $J \& K$ is worthwhile, primarily because of the proximity of the two regions, somewhat similar climate and topography, and their shared biogeographic history. At the generic and species level, chiropteran diversity of the two states is fairly comparable, with 18 genera and 32 species in J\&K (Bates \& Harrison, 1997; Chakraborty, 1983; Saikia et al., 2006) compared with 14 genera and 28 species in HP (Saikia et al., 2011). Among these, six genera and 16 species are exclusive to $\mathrm{J} \& \mathrm{~K}$ and two genera and 12 species are found only in HP, while 12 genera and 16 species are common to both the regions. Applying Simpson's coefficient, species resemblance translates to 57 percent. 


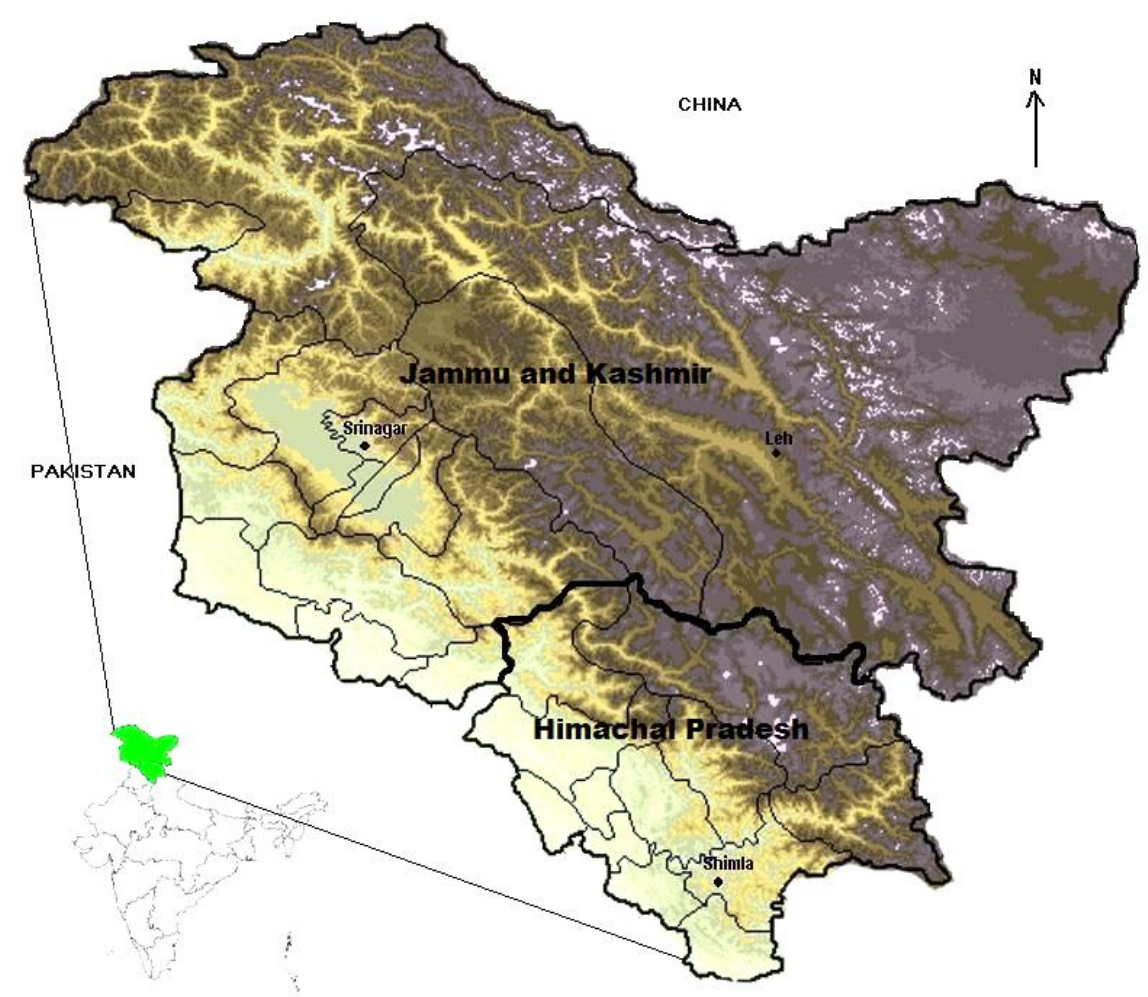

Figure 1: Map of the western Himalaya (Jammu \& Kashmir and Himachal Pradesh, India) showing administrative boundaries of Districts.

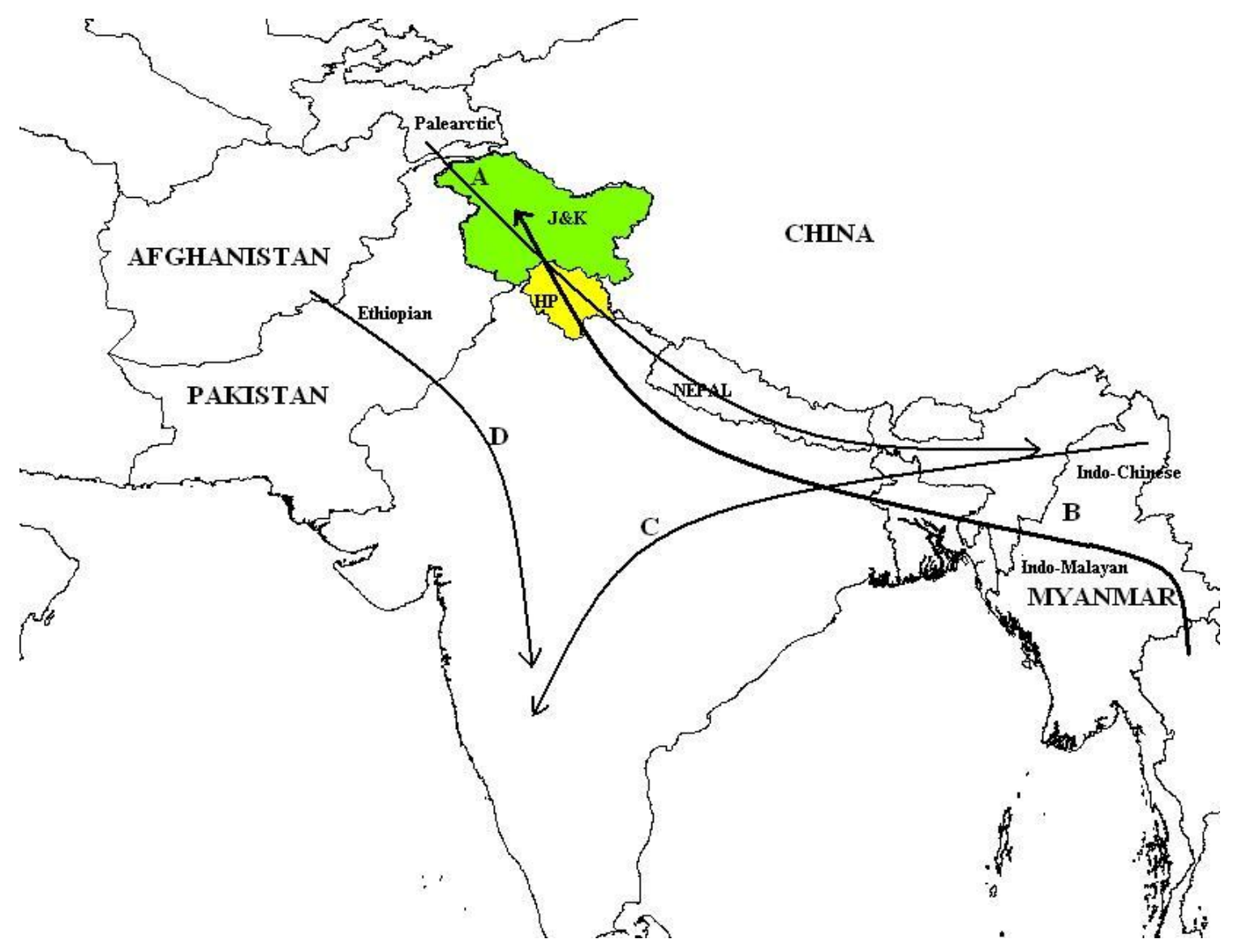

Figure 2: Hypothetical key routes of mammalian invasion to India indicating its possible course over Jammu \& Kashmir and Himachal Pradesh. (Modified from Kurup, 1974) 
Table 1: Zoogeographic affinity of the Chiropteran species of western Himalaya $(\mathrm{P}=$ presence $)$

\begin{tabular}{|c|c|c|c|}
\hline Family \& Species & $\begin{array}{c}\text { Himachal } \\
\text { Pradesh }\end{array}$ & $\begin{array}{l}\text { Jammu \& } \\
\text { Kashmir }\end{array}$ & $\begin{array}{c}\text { Zoogeographic } \\
\text { affinity }\end{array}$ \\
\hline \multicolumn{4}{|l|}{ Pteropodidae } \\
\hline Cynopterus sphinx Vahl,1797 & - & $\mathrm{P}$ & Oriental \\
\hline Pteropus giganteus Brünnich, 1782 & $\mathrm{P}$ & $\mathrm{P}$ & Oriental \\
\hline Rousettus leschenaulti (Desmarest, 1820) & $\mathrm{P}$ & $\mathrm{P}$ & Oriental \\
\hline \multicolumn{4}{|l|}{ Megadermatidae } \\
\hline Megaderma lyra Geoffroy, 1810 & $\mathrm{P}$ & $\mathrm{P}$ & Oriental \\
\hline \multicolumn{4}{|l|}{ Rhinolophidae } \\
\hline Rhinolophus affinis Horsfield, 1832 & $\mathrm{P}$ & - & Oriental \\
\hline Rhinolophus ferrumequinum (Schreber, 1774) & $\mathrm{P}$ & $\mathrm{P}$ & Palearctic \\
\hline Rhinolophus hipposideros (Bechstein, 1800) & - & $\mathrm{P}$ & Palearctic \\
\hline Rhinolophus lepidus Blyth, 1844 & $\mathrm{P}$ & - & Oriental \\
\hline Rhinolophus luctus Temminck, 1835 & $\mathrm{P}$ & - & Oriental \\
\hline Rhinolophus sinicus Anderson, 1905 & $\mathrm{P}$ & - & Oriental \\
\hline \multicolumn{4}{|l|}{ Hipposideridae } \\
\hline Hipposideros armiger Hodgson, 1835 & $\mathrm{P}$ & - & Oriental \\
\hline Hipposideros fulvus Gray, 1838 & - & $\mathrm{P}$ & Oriental \\
\hline \multicolumn{4}{|l|}{ Rhinopomatidae } \\
\hline Rhinopoma hardwickii Gray, 1831 & - & $\mathrm{P}$ & Ethiopian \\
\hline \multicolumn{4}{|l|}{ Vespertilionidae } \\
\hline Barbastella leucomelas (Cretzschmar, 1826) & $\mathrm{P}$ & $\mathrm{P}$ & Palearctic \\
\hline Eptesicus bottae (Peters, 1869) & - & $\mathrm{P}$ & Palearctic \\
\hline Eptesicus gobiensis Bobrinskii, 1926 & - & $\mathrm{P}$ & Palearctic \\
\hline Eptesicus serotinus(Schreber, 1774) & - & $\mathrm{P}$ & Palearctic \\
\hline Hypsugo savii (Bonaparte, 1837) & - & $\mathrm{P}$ & Palearctic \\
\hline Kerivoula hardwickii (Horsfield, 1824) & - & $\mathrm{P}$ & Oriental \\
\hline Miniopterus schreibersii (Kuhl, 1819) & $\mathrm{P}$ & - & Indeterminate \\
\hline Murina tubinaris (Scully, 1881) & $\mathrm{P}$ & $\mathrm{P}$ & Oriental \\
\hline Myotis blythii (Tomes, 1857) & $\mathrm{P}$ & $\mathrm{P}$ & Palearctic \\
\hline Myotis formosus (Hodgson, 1835) & $\mathrm{P}$ & $\mathrm{P}$ & Oriental \\
\hline Myotis longipes (Dobson, 1873) & - & $\mathrm{P}$ & Oriental \\
\hline Myotis muricola (Gray, 1846) & $\mathrm{P}$ & $\mathrm{P}$ & Oriental \\
\hline Myotis nipalensis (Dobson,1871) & $\mathrm{P}$ & $\mathrm{P}$ & Palearctic \\
\hline Myotis siligorensis (Horsfield, 1855) & $\mathrm{P}$ & - & Oriental \\
\hline Nyctalus leisleri (Kuhl, 1819) & $\mathrm{P}$ & $\mathrm{P}$ & Palearctic \\
\hline Nyctalus montanus (Barret-Hamilton, 1906) & $\mathrm{P}$ & - & Palearctic \\
\hline Nyctalus noctula (Schreber, 1774) & $\mathrm{P}$ & $\mathrm{P}$ & Palearctic \\
\hline Otonycteris hemprichii Peters, 1859 & - & $\mathrm{P}$ & Palearctic \\
\hline Pipistrellus ceylonicus (Kellart, 1852) & $\mathrm{P}$ & - & Oriental \\
\hline Pipistrellus coromandra (Gray, 1838) & $\mathrm{P}$ & $\mathrm{P}$ & Oriental \\
\hline Pipistrellus dormeri (Dobson, 1875) & $\mathrm{P}$ & $\mathrm{P}$ & Oriental \\
\hline Pipistrellus javanicus (Gray, 1838) & $\mathrm{P}$ & - & Oriental \\
\hline Pipistrellus paterculus Thomas, 1915 & - & $\mathrm{P}$ & Oriental \\
\hline Pipistrellus pipistrellus Schreber, 1774 & - & $\mathrm{P}$ & Palearctic \\
\hline Pipistrellus tenuis (Temminck, 1840) & $\mathrm{P}$ & $\mathrm{P}$ & Oriental \\
\hline Plecotus homochrous Hodgson, 1847 & $\mathrm{P}$ & $\mathrm{P}$ & Palearctic \\
\hline Plecotus wardi Thomas, 1911 & - & $\mathrm{P}$ & Palearctic \\
\hline Scotophilus heathii Horsfield, 1831 & - & $\mathrm{P}$ & Oriental \\
\hline Scotophilus kuhlii Leach, 1821 & $\mathrm{P}$ & - & Oriental \\
\hline Scotoecus pallidus Dobson, 1876 & $\mathrm{P}$ & - & Oriental \\
\hline Vespertilio murinus Linnaeus, 1758 & - & $\mathrm{P}$ & Palearctic \\
\hline
\end{tabular}

From a zoogeographic point of view, Oriental species (19) overwhelmingly dominate Palearctic (8) species in HP (affinity of one species being indeterminate), while the number of Palearctic (16) and Oriental (15) elements are almost equal with one Ethiopian counterpart in J\&K. Among the 16 species shared by both the regions, nine are oriental and the remaining seven are Palearctic species. The significant presence of Palearctic species in the chiropteran fauna of $\mathrm{J} \& \mathrm{~K}$ is primarily a consequence of its geographic location, which lies in the entrance of the key route of faunal inflow of Palearctic elements to India (Kurup, 1974). This incursion 
of Palearctic mammals through Northwestern India mostly proceeded towards the east although a feeble influx might have headed towards the south. Cooler and more humid conditions over much of India during some phases of Pleistocene enabled many Palearctic mammals to spread to peninsular India (Schaller, 1977). This is the reason that many of these Palearctic species in this area are also present in the eastern and north-east India while a few like Pipistrellus pipistrellus also occur in peninsular India (Korad \& Yardi, 2004). In spite of its position in the supposed route of mainstream Palearctic faunal invasion to India, relatively few Palearctic species could colonize HP. However, one should note that compared to the westward Oriental faunal invasion, eastward Palearctic faunal dispersal was smaller in magnitude. Many of these Palearctic bat species are associated with higher elevations and thus could not colonize lower areas. This also explains the absence of these elements in the immediate south of HP i.e. the plains of Punjab and Haryana. It may also be noted that the current species range may have little similarity to the past since climatic conditions have changed over time thereby affecting species distribution. The species composition we see today is a product of a long geological history enduring the vagaries of climate and physical events.

The preponderance of Oriental species in HP and also their significant presence in $J \& K$ is a testimony of a huge influx of Oriental elements to these regions. During the mid-Miocene period (18-11mya), much of India was probably covered with humid forest which was contiguous with that of Southeast Asia. Even in more recent times (Quaternary period), India probably experienced shrinking and expansion of forest cover due to multiple cycles of dry and wet periods (Karanth, 2003). Although it is difficult to deduce the time of westward Oriental faunal dispersal, expanding forest cover might have served as corridors for dispersal of those elements. However, as observed by Blanford (1901), starting east to Kashmir $\left(c .72^{0}\right.$ longitude), the number of typically Oriental species increases whereas these forms gradually disappear west of the Himalaya. Possibly prevailing drier conditions prevented further westward spread of these species. Kurup $(1966,1974)$ had shown that with respect to mammals, western India (including Jammu and Kashmir and HP) exhibit a good deal of faunal similarity with northeastern India, (Simpson's coefficient of 52). For Chiroptera, if the northwestern states of HP and Jammu and Kashmir are compared together (44 species) with northeastern India (63 species) (Bates \& Harrison, 1997; Thabah \& Bates, 2002), this similarity (28 species being common) also stands at a significant coefficient of 44. Faunal interchange is known to be one of the most dynamic and potent factors affecting faunal composition of a given region. Such resemblance strongly indicates past faunal interchange between the two regions, although the invasion from the eastern side was predominant as shown by comparatively larger portion of Oriental elements in western Himalaya (approx. 57\% of total bat species) compared to the smaller presence of Palearctic fauna in the northeastern India.

Disjunctive distribution of taxa: The supposed route of influx of Oriental elements to northern India is along Himalaya from north-eastern India. Interestingly, a few Oriental species like Cynopterus sphinx, Myotis longipes, Scotophilus heathii, Pipistrellus paterculus and Kerivoula hardwickii have reached Jammu and Kashmir (Chakraborty, 1983; Bates \& Harrison, 1997) but have not been recorded in HP which comes earlier on this invasion route. Similarly, a few Palearctic species from J\&K like Eptesicus serotinus and Pipistrellus pipistrellus have invaded northeastern India with a major disjunction in between. However, considering the lack of field studies, it is logical to expect at least some of these species to occur in the intervening area despite the disjunctive distribution of certain taxa. A number of earlier undocumented species namely Rhinolophus affinis, $R$. luctus, Myotis siligorensis, Hipposideros armiger and Miniopterus schreibersii have recently been recorded from HP (Saikia et al., 2004). Species like Myotis longipes, Kerivoula hardwickii, Pipistrellus paterculus and Pipistrellus pipistrellus are apparently disjunctively distributed in mainland India. Myotis longipes has a highly disjunct distribution in Kashmir and Meghalaya (Molur \& Srinivasulu, 2008). Taxonomy of small and big footed Myotis is complex and this species is very difficult to identify (Molur et al., 2002). Possibly the bat has thus far evaded detection in HP because of its rarity coupled with under- 
sampling and complex identification issues, or it may be absent altogether. Similarly, Kerivoula hardwickii is another uncommon bat in India and is known from a few localities in Assam, Mizoram, Meghalaya, Nagaland, West Bengal, J\&K and Karnataka (Rosell-Ambal et al., 2008; Pearch \& Writer, 2009). The apparent rarity of this species in India may reflect its secretive nature (Molur et al., 2002) and may be the reason for its supposed absence in HP. Eptesicus serotinus has been reported from Mussoorie in neighbouring Uttarakhand and it is very likely to be present in HP. Pipistrellus paterculus is known from $\mathrm{J} \& \mathrm{~K}$, Bihar, Assam, Manipur and Nagaland (Bates \& Harrison, 1997). Likewise, Pipistrellus pipistrellus is known from a few localities in $\mathrm{J} \& \mathrm{~K}$, Maharashtra and north-east India. If the observed disjunctive distribution of the above species is true, two alternative scenarios can be imagined. Firstly, some of these species could have dispersed to India through various smaller corridors other than the supposed major pathways of mammalian invasion. Alternatively, a few of them could also represent relict populations of earlier widespread species which became obliterated with changed climatic conditions, as suggested by Mani (1974b). Nonetheless, the presence of some of these Palearctic and Oriental elements in north-eastern India and also in northern India is again a testimony of past faunal exchange as discussed above.

Barring one species Nyctalus montanus, all other Palearctic species in HP are also present in $\mathrm{J} \& \mathrm{~K}$. However, it is considered likely that this species does occur in the state (unconfirmed report, Molur et al., 2002) due to the geographically forward position of J\&K when considering a Palearctic invasion to India, and due to the comparable physio-climatic conditions of $\mathrm{J} \& \mathrm{~K}$ and HP. Unfortunately, despite the impressive diversity and interesting zoogeographic milieu, the western Himalaya remains underexplored as far as species of Chiroptera are concerned. Our current understanding of the geographical and ecological distribution of bat species in this region is limited. Furthermore, in view of the recent advances in bat systematics, especially the discovery of cryptic diversity amongst some of the currently recognized forms, the existing inventories of bat fauna of the region probably substantially underestimate the species diversity. Thus, any zoogeographic inferences discussed above are necessarily crude. It is expected that intensive systematic studies will significantly add to the species inventory and will also shed new light on the zoogeography of the bat fauna of this region.

\section{Acknowledgements}

The first author is grateful to K. Venkatraman (Director, ZSI) and the officer-in-charge, ZSI (Solan and Shillong) for providing departmental facilities and encouragement. He also thanks to C. Radhakrishnan (ZSI) and A. Das for valuable comments. The Himachal Pradesh forest department is thanked for giving permission and manifold assistances rendered. Finally we would like to thank Judith Eger (Royal Ontario Museum - Canada) for editing the manuscript.

\section{Literature cited}

Ahmed, A., J. S. Rajput and S. C. Rai, 1990. An analysis of the Himalayan environment and guidelines for its management and ecologically sustainable development. The Environmentalist, 10 (4): 281-298.

Allen, G. M., 1908. Notes on Chiroptera. Bulletin of the Museum of Comparative Zoology, 52: 2561.

Bates, P. J. J. and D. L. Harrison, 1997. Bats of the Indian subcontinent. Harrison Zoological Museum, Kent: 268.

Bhat, H. R., S. M. Kulkarni and A. C. Mishra, 1983. Records of Mesostigmata, Ereynetidae and Pterygosomidae (Acarina) in Western Himalayas, Sikkim and hill districts of West Bengal. Journal of the Bombay Natural History Society, 80 (1): 91-110.

Blandford, W. T., 1888-1891. Fauna of British India, Mammalia. Taylor \& Francis, London: 617.

Blanford, W. T., 1901. The distribution of vertebrate animals in India, Burma and Ceylon. Philosophical Transactions of the Royal society of London, Series $B$ Containing papers of Biological Character, 194: 335-436.

Chakraborty, S., 1983. Contribution to knowledge of the mammalian fauna of Jammu and Kashmir, India. Records of Zoological Survey of India Occasional Paper, 38: 129. 
Corbet, G. B. and J. E. Hill, 1992. The Mammals of the Indomalayn Region. Natural History Museum/Oxford University Press: 488.

Dobson, G. E., 1872. Notes on some bats in the northwestern Himalaya. Proceedings of the Asiatic Society of Bengal, 1872, 208-210.

Dobson, G. E., 1873. Description of a new species of Vespertilio from northwestern Himalaya. Journal of the Asiatic Society of Bengal, 42 (2): 205-206.

Dodsworth, P. T. L., 1913. Notes on some mammals found in Simla Districts, the Simla hill States, and Kalka and adjacent country. Journal of the Bombay Natural History Society, 23 (3): 726-48.

Hinton, M and O. Thomas, 1926. Report No. 42. Kashmir and Punjab. Bombay Natural History Society's Mammal Survey of India, Burma and Ceylon. Journal of the Bombay Natural History Society, 31: 606-614.

Horáček, I., V. Hanak and J. Gaisler, 2000. Bats of the Palearctic region: A taxonomic and biogeographic review. Proceedings of the VIIIth European Bat Research Society, 1: 157.

Ives, J. D. and B. Messeril, 1989. The Himalayan Dilemma- Reconciling development and Conservation. Routledge, London: 324.

Johansson, U. S., P. Alstrom, U. Olsson, G. P. Ericson, P. Sundberg and T. D. Price, 2007. Build-up of the Himalayan avifauna through immigration: a biogeographical analysis of the Phylloscopus and Seicercus warblers. Evolution, 61 (2): 324-333.

Karanth, P. K., 2003. Evolution of disjunct distributions among wet-zone species of the Indian subcontinent: Testing various hypotheses using a phylogenetic approach. Current Science, 85 (9): 1276-1283.

Koopman, K., 1989. Distributional patterns of Indo-Malayan bats (Mammalia: Chiroptera). American Museum Novitates, 2942: 1-19.

Korad, V. S. and K. D. Yardi, 2004. New records of bats from central western India. Records of Zoological Survey of India, 103 (1-2): 171-177.
Kurup, G. U., 1966. Mammals of Assam and adjoining areas 1. An analytical study. Proceedings of the Zoological Society of Calcutta, 19: 1-21.

Kurup, G. U., 1974. Mammals of Assam and the mammal-geography of Assam. In: Mani, M. S. (ed.). Ecology and Biogeography in India. Dr. W. V. B. Junk Publishers, The Hague, Netherlands: 585-613.

Lindsay, H. M., 1927. Report No 44. Kangra and Chamba. Bombay Natural History Society's Mammal Survey of India. Journal of the Bombay Natural History Society, 31 (1): 597-607.

Mani, M. S., 1974a. Biogeography of the Himalayas. In: Mani, M. S. (ed.). Ecology and biogeography in India. Dr. W. V. B. Junk Publishers, The Hague, Netherlands: 664-681.

Mani, M. S., 1974b. Biogeographical evolution in India. In: Mani, M. S. (ed.) Ecology and biogeography in India. Dr. W. V. B. Junk Publishers, The Hague, Netherlands: 698-724.

Martens, J. and S. Eck., 1995. Towards an ornithology of the Himalayas: systematics, ecology and vocalizations of Nepal birds. Bonn Zoological Monograph, 38:1-445.

Mehta, H. S. and J. M. Julka, 2002. Mountains: North-West Himalaya. In: Alfred, D. and Sanyal (eds.). Ecosystems of India. ENVIS Center, Zoological Survey of India, Kolkata: 51-72.

Molur, S., G. Marimuthu, C. Srinivasulu, S. Mistry, A. M Hutson, P. J. J. Bates, S. Walker, K. Padma Priya, and A. R. Binu Priya (eds.), 2002. Status of South Asian Chiroptera: Conservation Assessment and Management Plan (C.A.M.P.) Workshop Report, 2002. Zoo Outreach Organisation, CBSG South Asia and WILD, Coimbatore, India: 322.

Molur, S. and C. Srinivasulu, 2008. Myotis longipes. In: IUCN Red List of Threatened Species. Version 2012.1. 〈www.iucnredlist.org>. Downloaded on 24 September 2012.

Mittermeier, R. A., R. P. Gil, M. Hoffmann, J. Pilgrim, T. Brooks, C. G. Mittermeier, J. Lamoreux and G. A. B. da Fonseca, 2004. Hotspots revisited: Earth's biologically richest and most endangered terrestial ecosystems. Cemex, Mexico. 
Nandi, S. N., R. Pant and K. S. Rao, 2000. Indian Himalaya: A demographic database. ENVIS Monograph 2, G. B. Pant Institute of Himalayan Environment and Development, Almora: 75.

Nath, S., 1979. On a collection of Microchiropterid bats from Kashmir valley and adjacent areas with some new records. Proceedings of Indian Science Congress III(D): 3.

Nath, S., 1985. On the extension of the range of Pipistrellus paterculus (Thomas) to Poonch Vallley, (Jammu and Kashmir State). Journal of the Bombay Natural History Society, 82 (2): 396.

Nath, S., 1987. On a collection of long eared bats of the genera Otonycteris Peters and Plecotus Geoffroy (Family: Vespertilionidae) from Kashmir valley. Journal of the Bombay Natural History Society, 84 (2): 425-426.

Pearch, M. J. and T. O. D. Writer (eds.), 2009. South East Asian Bat Database. Harrison Institute, Sevenoaks, UK.

Roberts, T. J., 1977. The Mammals of Pakistan. Ernest Benn Limited, London and Tonbridge: 361.

Rodger, W. A. and H. S. Panwar, 1988. Planning a wildlife protected area network in India. Vol.1 $\& 2$, Wildlife Institute of India, Dehra Dun.

Rosell-Ambal, G., B. Tabaranza, L. Heaney, S. Molur and C. Srinivasulu, 2008. Kerivoula hardwickii. In: IUCN 2012. IUCN Red List of Threatened Species. Version 2012.1. <www.iucnredlist.org>. Downloaded on 24 September 2012.

Saikia, U., R. M. Sharma and V. K. Mattu, 2004. New records of bats from Himachal Pradesh with some ecological notes. The Indian Forester, 130 (10): 1204-1208.

Saikia, U., R. M. Sharma and D. K. Sharma, 2006. Record of fulvous leaf-nosed bat Hipposideros fulvus Gray, 1838 from Jammu and Kashmir, India. Zoos Print Journal, 21 (3): 2197.

Saikia, U., M. L. Thakur, M. Bawri and P. C. Bhattacharjee, 2011. An inventory of the Chiropteran fauna of Himachal Pradesh, northwest India with some ecological observations. Journal of Threatened Taxa, 4 (3): 1637-1655.
Schaller, G. B., 1977. Mountain monarchs: Wild sheep and goats of the Himalaya. University of Chicago Press, Chicago: 425.

Sharma, B. D. and T. Sharma, 1976. Some mammal record for Jammu Province (Jammu and Kashmir State). Indian Poultry Review, 8: 15-17.

Simmons, N. B., 2005. Order Chiroptera. In: Wilson and Reeder (eds.). Mammal Species of the World: A Taxonomic and Geographic Reference. Smithsonian Institution Press, Washington DC: 312-529.

Simpson, G. G., 1960. Notes on the measurements of faunal resemblance. American Journal of Science, 258: 300-311.

Spitzenberger, F., P. P. Strelkov, H. Winkler and E. Haring. 2006. A preliminary revision of the genus Plecotus (Chiroptera, Vespertilionidae) based on genetic and morphological results. Zoologica Scripta, 35: 187-230.

Srinivasalu, C. and B. Srinivasalu, 2001. Bats of Indian subcontinent: An update. Current Science, 80 (11): 1378-1380.

Teeling, E. C., M. S. Springer, O. Madsen, P. Bates, S. J. O'Brien and W. J. Murphy, 2005. A molecular phylogeny for bats illuminates biogeography and the fossil record. Science, 307: 580-584.

Thabah, A. and P. J. J. Bates, 2002. Recent record of Otomops wroughtoni (Thomas, 1913) (Chiroptera: Molossidae) from Meghalaya, NE India. Acta Zoologica Academiae Scientiarum Hungaricae, 48 (3): 251-253.

Thomas, O., 1911. New Asiatic Muridae. Annals and Magazines of Natural History, 7: 205-209.

Thomas, O., 1926. A new Myotis from Ladak. Annals and Magazines of Natural History, 9 (17): 609-610. 